\title{
Fundamentals of Silico-Ferrite of Calcium and Aluminium (SFCA) and SFCA-I Iron Ore Sinter Bonding Phase Formation: Effects of Titanomagnetite-based Ironsand and Titanium Addition
}

\author{
Nathan A. S. WEBSTER, ${ }^{1 / *}$ Jack G. CHURCHILL, ${ }^{1,2)}$ Felipe TUFAILE, ${ }^{1,3)}$ Mark I. POWNCEBY, ${ }^{11}$ \\ James R. MANUEL ${ }^{4)}$ and Justin A. KIMPTON ${ }^{5)}$ \\ 1) CSIRO Mineral Resources, Private Bag 10, Clayton South, VIC, 3169 Australia. \\ 2) Chemical and Biomolecular Engi- \\ neering, The University of Melbourne, Parkville, VIC, 3010 Australia. \\ 3) University of São Paolo, São Paolo, 05508-900, \\ SP, Brazil. $\quad$ 4) CSIRO Mineral Resources, PO Box 883, Kenmore, QLD, 4069 Australia. \\ 800 Blackburn Rd, Clayton, VIC, 3168 Australia. \\ 5) Australian Synchrotron,
}

(Received on March 29, 2016; accepted on June 23, 2016)

\begin{abstract}
The thermal decomposition of titanomagnetite-based ironsand, and the effects of ironsand addition on the formation of SFCA and SFCA-I iron ore sinter bonding phases, was investigated using in situ X-ray diffraction. Titanium incorporation into the SFCA and SFCA-I structures was investigated via phase equilibria experiments and subsequent ex situ characterisation. Increasing ironsand addition from 1.3 to 6.7 and to 13.8 mass \% in an otherwise synthetic sinter mixture composition designed to form SFCA-I did not significantly affect the thermal stability range of SFCA-I ( 1 373-1523 K), nor did it significantly affect the maximum concentration of SFCA-I attained (42-46 mass\%). The main effect of ironsand addition was a small reduction in the thermal stability range of another complex calcium-rich ferrite, $\gamma$ CFF. In comparison, increasing ironsand addition from 2.4 to 3.9 and to 11.6 mass \% in an otherwise synthetic sinter mixture composition designed to form SFCA resulted in a decrease in the maximum SFCA-I concentration, from 30 , to 24 and 16 mass \%, respectively, with a corresponding increase in the concentration of SFCA (16, to 23 and 33 mass\%). The phase equilibria studies revealed that SFCA can incorporate more titanium in its structure (up to 1.2 mass $\% \mathrm{TiO}_{2}$ ) than SFCA-I $\left(0.6\right.$ mass $\% \mathrm{TiO}_{2}$ ). The 'total SFCA' (i.e. SFCA-I + SFCA) content decreased as the ironsand content increased, as well as there being a general shift to higher temperature of the total SFCA concentration curves. Such effects are likely to exert an influence on the physical properties of iron ore sinter, as well as affecting sintering fuel requirements.
\end{abstract}

KEY WORDS: iron ore sinter; ironsand; titanomagnetite; thermal decomposition; SFCA; SFCA-I; in situ X-ray diffraction; quantitative phase analysis; phase formation mechanisms; phase equilibria; Ti substitution.

\section{Introduction}

'SFCA' (Silico-Ferrite of Calcium and Aluminium) phases are key bonding materials within industrial iron ore sinter. ${ }^{1)}$ Sinter is a major feedstock material of blast furnaces, utilized extensively worldwide in the production of steel from iron ore. Increased understanding of (i) the compositional and thermal stability of SFCA phases, (ii) their formation mechanisms, and (iii) the effect of different processing parameters on (i) and (ii) has the potential to improve the efficiency of the sintering process by being better able to predict optimal sintering conditions (e.g. temperature, oxygen partial pressure) required to produce high-quality product based on the chemical composition and physical characteristics of a given iron ore sinter mixture. Additionally, it may allow better prediction of the chemical and physical modifications of a particular iron ore sinter mixture required to produce high-quality product for given

* Corresponding author: E-mail: nathan.webster@csiro.au DOI: http://dx.doi.org/10.2355/isijinternational.ISIJINT-2016-162 sintering conditions.

The SFCA in iron ore sinter has been categorized in the literature on the basis of composition, morphology and crystal structure into two main types. The first is a high-Fe, low-Si form called SFCA-I which has a characteristic platy (also described as acicular) morphology. Mumme et al. ${ }^{2)}$ reported that an SFCA-I phase in industrial sinter contained 84 mass $\% \mathrm{Fe}_{2} \mathrm{O}_{3}, 13$ mass $\% \mathrm{CaO}, 1$ mass $\% \mathrm{SiO}_{2}$ and 2 mass $\% \mathrm{Al}_{2} \mathrm{O}_{3}$, and also synthesized SFCA-I material which had the composition 83.2 mass $\% \mathrm{Fe}_{2} \mathrm{O}_{3}, 12.6$ mass\% $\mathrm{CaO}$ and 4.2 mass $\% \mathrm{Al}_{2} \mathrm{O}_{3}$. The second SFCA type is a low-Fe form called SFCA which is described as having a prismatic or columnar morphology. SFCA found in industrial sinters typically contains 60-76 mass $\% \mathrm{Fe}_{2} \mathrm{O}_{3}, 13-16$ mass $\%$ $\mathrm{CaO}, 3-10$ mass $\% \mathrm{SiO}_{2}$, 4-10 mass $\% \mathrm{Al}_{2} \mathrm{O}_{3}$ and $0.7-1.5$ mass\% $\mathrm{MgO}^{3,4)}$ Patrick and Pownceby ${ }^{5)}$ systematically resolved the equilibrium solid solution range and thermal stability of SFCA within the quaternary system $\mathrm{Fe}_{2} \mathrm{O}_{3}-$ $\mathrm{CaO}-\mathrm{SiO}_{2}-\mathrm{Al}_{2} \mathrm{O}_{3}$ in air in the range $1513 \mathrm{~K}$ to $1663 \mathrm{~K}$. Such a rigorous investigation of solid solution limits and thermal stability has not been performed for SFCA-I, with 
the study of Mumme et $a l .^{2)}$ the most detailed description of the stability of SFCA-I under equilibrium conditions. It has been suggested that a texture of intersecting microplates characteristic of SFCA-I imparts high strength and reducibility into iron ore sinter, and sinters containing significant amounts of this phase are of higher quality than those containing mostly SFCA. ${ }^{6,7)}$ The key to obtaining SFCA-I in sinter product is preserving it during the heating stage of the sintering process, since SFCA-I does not crystallize from melt during cooling. ${ }^{6)}$ A number of recent investigations ${ }^{8-14)}$ have utilised in situ powder X-ray diffraction (XRD) in order to establish the formation mechanisms of SFCA and SFCA-I under simulated sintering conditions from synthetic starting sinter mixtures heated in the range 298-1 $623 \mathrm{~K}$, under oxygen partial pressures $\left(\mathrm{pO}_{2}\right)$ in the range 0.21 to $1 \times$ $10^{-4} \mathrm{~atm}$. XRD is an ideal technique to distinguish between SFCA and SFCA-I, since the crystal structures of the two phases are distinct. ${ }^{2,15)}$

Recently, Bluescope's Port Kembla sinter plant has begun incorporating $2-3$ mass $\%$ fine grained $(<150 \mu \mathrm{m})$ New Zealand ironsand as a component of its iron ore sinter blend. ${ }^{16)}$ The ironsand is composed predominantly of titanomagnetite $\left(\mathrm{Fe}_{3-x} \mathrm{Ti}_{x} \mathrm{O}_{4}\right)$ containing 7.9 mass $\% \mathrm{TiO}_{2}$, with minor amounts of hematite, ilmenite, quartz, pyroxene and aluminosilicates. Ironsand is a relatively cheap source of iron, and the introduction of a minor amount of titanium-bearing ore into the blast furnace burden has been demonstrated to extend blast furnace operating campaigns due to the formation of titanium carbonitrides on the hearth lining. ${ }^{17)}$ Early work by Bristow and $\mathrm{Loo}^{18)}$ found that addition of up to 2 mass $\%$ titanomagnetite did not affect sinter properties, but a bulk titanomagnetite content of greater than 3 mass $\%$ had a significant negative effect on the reduction degradation index (RDI). Paananen and Kinnunen also reported a negative effect on sinter RDI through the addition of rutile $\left(\mathrm{TiO}_{2}\right) .{ }^{19)}$ The effect of $\mathrm{TiO}_{2}$ addition (in the form of analytical grade $\mathrm{TiO}_{2}$ ) on the equilibrium sinter phases at $\mathrm{pO}_{2}=$ $5 \times 10^{-3}$ atm has recently been investigated, and reported that Ti existed mainly in perovskite, the phase concentration of which increased with increasing $\mathrm{TiO}_{2}$ addition. ${ }^{20)}$ This study also reported a small decrease in SFCA concentration of 45 to 42 mass $\%$ as the mass $\%$ of $\mathrm{TiO}_{2}$ increased from 0 to $12 \mathrm{mass} \%$. More recently, the effect of $\mathrm{TiO}_{2}$ addition on the sintering behaviour of an iron ore sinter blend has been studied in laboratory tests by Dehghan-Manshadi et al. ${ }^{21)}$ Their results showed a considerable effect of $\mathrm{TiO}_{2}$ on sinter strength, where the tumble index increased with increasing $\mathrm{TiO}_{2}$ (up to 2 mass\%). However, addition of more than 2 mass $\% \mathrm{TiO}_{2}$ to the blend decreased its overall strength. As with the study by Ren et al., ${ }^{20)}$ Dehghan-Manshadi et al. reported perovskite formation, with greater volume fractions obtained with increasing $\mathrm{TiO}_{2}$. Wang et al. ${ }^{16)}$ recently demonstrated that heating ironsand-doped sinter blends under reduced conditions caused individual ironsand particles to undergo assimilation beginning with diffusion of $\mathrm{Ca}$ from the sinter into the ironsand. This decreased the melting point of titanomagnetite which accelerated further assimilation and led to the formation of the perovskite phase.

Although the effects of titanomagnetite ironsand and $\mathrm{TiO}_{2}$ addition on bulk sinter properties have been investigated, the effect of ironsand addition on the thermal stability ranges of the SFCA-I and SFCA phases during heating, and the variations of the concentrations of SFCA-I, SFCA and precursor phases as a function of temperature, are not known in detail. The first aim of the current investigation was to determine the effect of ironsand addition on SFCA and SFCA-I phase formation during heating, with titanomagnetite added to two synthetic mixtures, the first having a bulk composition designed to form SFCA-I, and the other designed to form SFCA. In situ XRD measurements with subsequent Rietveld refinement-based quantitative phase analysis (QPA) was employed to elucidate phase evolution during heating. As part of the study, the thermal decomposition of New Zealand ironsand was also characterized in order to understand how the breakdown may influence the formation of SFCA and SFCA-I during heating. In addition, other than Ti being identified as a very minor constituent in SFCA-I by Mumme et $a l^{2)}$ it is unclear as to whether Ti substitutes to any significant extent into either the SFCA or SFCA-I crystal structures. The second aim of the current investigation was to determine the extent of substitution of Ti into the SFCA and SFCA-I structures by conducting phase equilibration experiments where synthetic SFCA-I and SFCA starting compositions were doped with $\mathrm{TiO}_{2}$. The samples were subject to equilibration at high temperature followed by ex situ quantitative measurements to determine the degree of Ti incorporation.

\section{Experimental}

\subsection{In situ XRD Sample Preparation}

The ironsand used here was sourced from Bluescope and has previously been characterised in detail. ${ }^{16)}$ In summary, its bulk composition in terms of oxides is 36.0 mass $\%$ $\mathrm{FeO}, 43.4$ mass $\% \mathrm{Fe}_{2} \mathrm{O}_{3}$ (58.3 mass $\%$ total $\mathrm{Fe}$ ), 7.9 mass $\%$ $\mathrm{TiO}_{2}, 0.6$ mass $\% \mathrm{CaO}, 0.4$ mass $\% \mathrm{Al}_{2} \mathrm{O}_{3}, 2.3$ mass $\% \mathrm{SiO}_{2}$, 3.1 mass $\% \mathrm{MgO}$ (minor amounts of $\mathrm{Cr}_{2} \mathrm{O}_{3}, \mathrm{~V}_{2} \mathrm{O}_{5}, \mathrm{MnO}$, $\mathrm{ZrO}_{2}, \mathrm{P}_{2} \mathrm{O}_{5}$ and $\mathrm{ZnO}$ also present), and its mineral phase composition determined by XRD is $84.1,1.7,3.0$ and 0.5 mass $\%$ titanomagnetite, ilmenite $\left(\mathrm{FeTiO}_{3}\right)$, hematite $\left(\mathrm{Fe}_{2} \mathrm{O}_{3}\right)$ and quartz $\left(\mathrm{SiO}_{2}\right)$, respectively, with the remaining 10.7 mass $\%$ being poorly crystalline or low abundance material comprised mainly of pyroxene and aluminosilicates. The titanomagnetite is assigned a formula of $\mathrm{Fe}_{2.73} \mathrm{Ti}_{0.27} \mathrm{O}_{4}$, based on results from quantitative electron probe microanalysis (EPMA). The ironsand was micronized separately and added in progressively higher amounts to (i) the base SFCAI mixture - bulk composition 83.2 mass $\% \mathrm{Fe}_{2} \mathrm{O}_{3}, 12.6$ mass $\% \mathrm{CaO}$ and 4.2 mass $\% \mathrm{Al}_{2} \mathrm{O}_{3}$ - previously investigated in detail by Webster et al., ${ }^{12)}$ and (ii) the base SFCA mixture - bulk composition 77.36 mass $\% \mathrm{Fe}_{2} \mathrm{O}_{3}, 14.08$ mass $\%$ $\mathrm{CaO}, 3.56$ mass $\% \mathrm{SiO}_{2}$ and $5 \mathrm{wt} \% \mathrm{Al}_{2} \mathrm{O}_{3}$ - previously investigated by Scarlett et al. ${ }^{8,9)}$ and Webster et al. ${ }^{10,11,14)} \mathrm{It}$ is important to note the base SFCA-I and SFCA mixtures were themselves composed of hematite, calcite $\left(\mathrm{CaCO}_{3}\right)$, quartz and gibbsite $\left(\mathrm{Al}(\mathrm{OH})_{3}\right)$.

The ironsand/SFCA-I and ironsand/SFCA samples were mixed under acetone in a mortar and pestle with an intermediate drying and remixing stage to ensure homogenization. Three ironsand/SFCA-I samples were prepared, with ironsand contents of $1.3,6.7$ and 13.8 mass $\%$. This equates to levels of $0.1,0.5$ and 1 mass $\% \mathrm{TiO}_{2}$ in the mixtures. 
Importantly, the bulk $\mathrm{Fe}, \mathrm{Ca}$, and $\mathrm{Al}$ ratios were maintained at their pre-doped SFCA-I ratios by adding additional calcite and gibbsite as necessary after addition of the ironsand. It is also important to keep in mind that the compositions were designed to model the reactive ultrafine $(<1 \mathrm{~mm})$ coating component of a sinter mix (shown schematically in Ref. 10), rather than being representative of the bulk composition of a sinter blend containing coarse nuclei (up to $6.3 \mathrm{~mm}$ in size), gangue and flux particles. Three ironsand/SFCA samples were also prepared, with ironsand contents of 2.4, 3.9 and 11.6 mass $\%$ (equivalent to $0.2,0.3$ and 0.9 mass $\% \mathrm{TiO}_{2}$ ).

\subsection{In situ XRD Experimentation and Quantitative Phase Analysis}

For each of the ironsand/SFCA-I mixtures, as well as the unmixed, micronized ironsand, in situ XRD experiments were performed using an INEL diffractometer, which incorporates a CPS120 position sensitive detector allowing for simultaneous collection of up to $120^{\circ} 2 \theta$ of diffraction data. The Co tube was operated at $40 \mathrm{kV}$ and $35 \mathrm{~mA}$. An Anton Paar HTK10 high-temperature chamber employing a Pt resistance strip heater containing a sample well measuring $\sim 20 \times 7 \times 0.2 \mathrm{~mm}$ was fitted to the diffractometer. Samples were heated over the range $298-1623 \mathrm{~K}$ under a flow of a 0.5 vol pet $\mathrm{O}_{2}$ in $\mathrm{N}_{2}$ gas mixture (to give a nominal oxygen partial pressure of $\left.\mathrm{pO}_{2}=5 \times 10^{-3} \mathrm{~atm}\right)$. The oxygen partial pressure was chosen based on the work of Hsieh and Whiteman, who determined that this $\mathrm{pO}_{2}$ maximized the formation of $\mathrm{Ca}$-rich ferrites whilst still producing mineral assemblages similar to those found in industrial sinters. ${ }^{22)}$ $\mathrm{XRD}$ data were collected over the range $10^{\circ} \leq 2 \theta \leq 120^{\circ}$ continuously throughout heating, with individual datasets collected for $1 \mathrm{~min}$.

For the ironsand/SFCA mixtures, in situ synchrotron XRD (S-XRD) experiments were performed on the powder diffraction beamline at the Australian Synchrotron. ${ }^{23)}$ An Anton Paar HTK 2000 high-temperature chamber employing a Pt resistance strip heater was fitted to the beamline. XRD data were collected over the range $6^{\circ} \leq 2 \theta \leq 86.5^{\circ}$ continuously throughout heating, with individual datasets collected for $1 \mathrm{~min}$, using an X-ray wavelength of 1.1044 A calibrated using LaB6 (NIST 660b line position standard). The superior angular resolution of the synchrotron data, compared to the laboratory INEL data, is beneficial to distinguish between SFCA and SFCA-I which have closely spaced reflections. The superior peak-to-background ratio of synchrotron data also assists in identifying phases with low abundance.

For each in situ experiment a heating rate of $20 \mathrm{~K} \mathrm{~min}^{-1}$ was used from $298-873 \mathrm{~K}$. The rate was then reduced to 10 $\mathrm{K} \mathrm{min}^{-1}$ for the $873-1623 \mathrm{~K}$ interval which corresponded to the period of $\mathrm{Ca}$-rich ferrite phase formation and decomposition. The temperature was measured by a Pt/PtRh10\% thermocouple connected to the underside of the platinum strip directly underneath the sample. The time-temperature profile used for these experiments is significantly slower than those encountered in industrial sintering. It was chosen so as to monitor phase formation with reasonable temperature resolution and to provide XRD data with reasonable counting statistics in order to establish trends in phase behaviour with increasing ironsand concentration.
The temperatures of phase formation/transformation given throughout the manuscript are those at the start - which is when the temperatures were automatically recorded - of the relevant data set. The uncertainty in these temperature values, therefore, was the difference between the temperatures at the start of successive data sets. The decomposition of precursor phases and the formation of new phases as the experiments progressed was visualized by stacking the datasets to produce plots of accumulated data with temperature plotted $v s 2 \theta$, viewed down the intensity axis.

Rietveld refinement-based QPA was performed on the individual datasets using TOPAS (Version 5). ${ }^{24)}$ The crystal structure data of Blake et al., Maslen et al., Saalfeld and Wedde, Lager et al., Schulz and Tscherry, Oftedal, Berastegui et al., Decker and Kasper, Arakcheeva et al., Arakcheeva and Karpinksii, Mumme et al., Hamilton et al., Hamilton, Wechsler et al., Pecharroman et al., Becerro et al. and Pauling were used for $\mathrm{Fe}_{2} \mathrm{O}_{3}, \mathrm{CaCO}_{3}, \mathrm{Al}(\mathrm{OH})_{3}$, $\alpha-\mathrm{SiO}_{2}, \beta-\mathrm{SiO}_{2}, \mathrm{CaO}, \mathrm{C}_{2}\left(\mathrm{~F}_{1-x} \mathrm{~A}_{x}\right), \mathrm{CF}, \mathrm{CFA}, \gamma-\mathrm{CFF}, \mathrm{SFCA}-$ I, SFCA, $\mathrm{Fe}_{3} \mathrm{O}_{4}, \mathrm{Fe}_{2.73} \mathrm{Ti}_{0.27} \mathrm{O}_{4}, \gamma-\mathrm{Fe}_{2} \mathrm{O}_{3}$, perovskite and $\mathrm{Fe}_{2} \mathrm{TiO}_{5}$, respectively. ${ }^{2,15,25-39)}$ The use of the QPA algorithm embodied in TOPAS returns relative, rather than absolute, concentrations for crystalline phases in a system if amorphous material, including melt phases, are present. Previous work has demonstrated that amorphous $\mathrm{Al}_{2} \mathrm{O}_{3}$ is present in these systems after the decomposition of $\mathrm{Al}(\mathrm{OH})_{3}{ }^{8-14)}$ Therefore, absolute phase concentrations as a function of temperature were determined, via an 'external standard' methodology. ${ }^{12)}$

\subsection{Phase Equilibria Experiments and Ex situ Charac- terisation}

Table 1 shows the bulk composition of the samples in terms of mass $\%$ oxides and elements. $\mathrm{TiO}_{2}$ was added to the base SFCA and SFCA-I mixtures described in Section 2.1 in the form of a 94 mass $\%$ rutile $/ 6 \mathrm{wt} \%$ anatase powder (Aldrich, 99.99\%). Approximately $0.5 \mathrm{~g}$ of each sample was pelletised and heated at temperature $(1513 \mathrm{~K}$ for the SFCA-I-1 $1 \mathrm{TiO}_{2},-2 \mathrm{TiO}_{2},-3 \mathrm{TiO}_{2}$ samples, and $1533 \mathrm{~K}$ for the $\mathrm{SFCA}-1 \mathrm{TiO}_{2},-2 \mathrm{TiO}_{2}$ and $-3 \mathrm{TiO}_{2}$ samples, with both temperatures below the melting points) for $48 \mathrm{hr}$ (with intermediate grinding and re-pelleting after $24 \mathrm{hr}$ ) in a platinum crucible in a vertical tube furnace in air. The samples were confirmed to be at equilibrium by establishing that XRD

Table 1. Nominal compositions, in mass $\%$ oxides, of the mixtures used in the phase equilibria experiments (all Ti added as $\mathrm{TiO}_{2}$ ) designed to determine the extent of substitution of Ti into SFCA and SFCA-I.

\begin{tabular}{cccccc}
\hline & \multicolumn{5}{c}{ Concentration (oxide mass\%) } \\
\cline { 2 - 6 } Sample & $\mathrm{Fe}_{2} \mathrm{O}_{3}$ & $\mathrm{CaO}$ & $\mathrm{SiO}_{2}$ & $\mathrm{Al}_{2} \mathrm{O}_{3}$ & $\mathrm{TiO}_{2}$ \\
\hline SFCA-I-1TiO $_{2}$ & 82.32 & 12.48 & - & 4.20 & 1.00 \\
$\mathrm{SFCA} \mathrm{I}-2 \mathrm{TiO}_{2}$ & 81.49 & 12.36 & - & 4.16 & 2.00 \\
$\mathrm{SFCA} \mathrm{I}-3 \mathrm{TiO}_{2}$ & 80.66 & 12.23 & - & 4.11 & 3.00 \\
& & & & & \\
$\mathrm{SFCA}-1 \mathrm{TiO}_{2}$ & 76.59 & 13.94 & 3.52 & 4.95 & 1.00 \\
$\mathrm{SFCA}_{2} 2 \mathrm{TiO}_{2}$ & 75.81 & 13.80 & 3.49 & 4.90 & 2.00 \\
$\mathrm{SFCA}-3 \mathrm{TiO}_{2}$ & 75.04 & 13.66 & 3.45 & 4.85 & 3.00 \\
\hline
\end{tabular}


patterns collected for the samples after $24 \mathrm{hrs}$ heating, and after $48 \mathrm{hrs}$, were the same. The temperature adjacent to the crucible was measured using a Pt/PtRh13\% thermocouple connected to an ice-point cell, and temperatures are considered accurate to $\pm 10 \mathrm{~K}$. Samples were rapidly quenched by dropping the crucible to the cold end of the furnace. Samples were crushed and prepared for ex situ EPMA, which was performed using a JEOL JXA-8900R Superprobe. Hematite, wollastonite $\left(\mathrm{CaSiO}_{3}, \mathrm{CS}\right)$, "Magalox" (a synthetic spinel, composition $\mathrm{MgAl}_{2} \mathrm{O}_{4}$ ) and rutile were used as standards for the microprobe analyses which were conducted in wavelength dispersive mode using an accelerating voltage of $15 \mathrm{kV}$, a beam current of $20 \mathrm{nA}$, a beam diameter of $5 \mu \mathrm{m}$ and counting times of $15 \mathrm{sec}$ on the peak and $7.5 \mathrm{sec}$ on the background.

\section{Results and Discussion}

\subsection{In situ Thermal Decomposition of Ironsand}

Figure 1 shows a plot of accumulated in situ XRD data, viewed down the intensity axis and with temperature plotted vs $2 \theta$, for the experiment performed to examine the thermal decomposition of the ironsand sample. Reflections for $\mathrm{Fe}_{2.73} \mathrm{Ti}_{0.27} \mathrm{O}_{4}$ (ICDD card no. 01-075-1374 is the closest match), $\mathrm{Fe}_{2} \mathrm{O}_{3}$ (ICDD no. 33-0664) and quartz ( $\mathrm{SiO}_{2}$, ICDD 33-1161) were observed at room temperature. Reflections for $\mathrm{FeTiO}_{3}$ (ICDD 29-0733) are closely adjacent to the $\mathrm{Fe}_{2} \mathrm{O}_{3}$ reflections, and are therefore not separately labeled in Fig. 1. Above $\sim 573 \mathrm{~K}$, maghemite $\left(\gamma-\mathrm{Fe}_{2} \mathrm{O}_{3}\right.$, ICDD 01-0763169 ) reflections were observed, above $\sim 973 \mathrm{~K}$ reflections for pseudobrookite $\left(\mathrm{Fe}_{2} \mathrm{TiO}_{5}\right.$, ICDD 41-1432), and above $\sim 1523 \mathrm{~K}$ reflections from a spinel phase (designated $\mathrm{Fe}_{3} \mathrm{O}_{4}$ because the concentrations of Ti and other possible impurity elements in this phase are unknown).

Figure 2 shows the Rietveld fit for the ironsand sample at 298 K, and Fig. 3 shows the results of the Rietveld refinement-based QPA for the unmixed ironsand sample over the range 298-1 $623 \mathrm{~K}$. Notably, oxidation of $\mathrm{Fe}_{2.73} \mathrm{Ti}_{0.27} \mathrm{O}_{4}$ to $\gamma-\mathrm{Fe}_{2} \mathrm{O}_{3}$ was extensive by $653 \mathrm{~K}$ (i.e. the concentration of $\gamma-\mathrm{Fe}_{2} \mathrm{O}_{3}$ at this temperature was 59 mass $\%$, and the decrease in $\mathrm{Fe}_{2.73} \mathrm{Ti}_{0.27} \mathrm{O}_{4}$ concentration in the range $505-653 \mathrm{~K}$ was

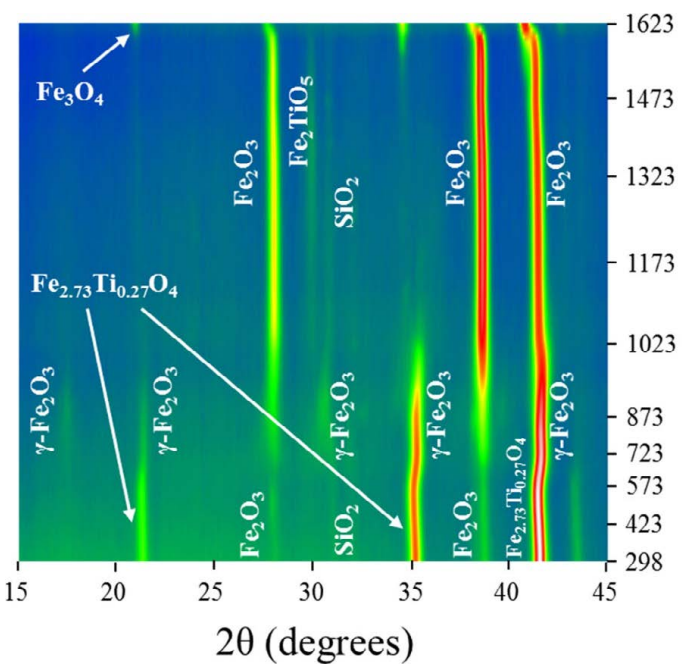

Fig. 1. In situ XRD data collected for the New Zealand ironsand sample, viewed down the intensity axis, over the range

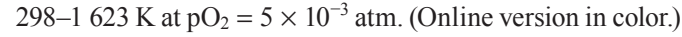

61 mass \%). This suggests that the Ti was incorporated into the $\gamma-\mathrm{Fe}_{2} \mathrm{O}_{3}$ structure to form a titanomaghemite phase. In the range $653-831 \mathrm{~K}$ the $\gamma-\mathrm{Fe}_{2} \mathrm{O}_{3}$ concentration initially reaches a plateau before further oxidation of $\mathrm{Fe}_{2.73} \mathrm{Ti}_{0.27} \mathrm{O}_{4}$ results in the formation of additional $\mathrm{Fe}_{2} \mathrm{O}_{3}$ and minor $\mathrm{FeTiO}_{3}$. In the range $860-1070 \mathrm{~K}, \gamma-\mathrm{Fe}_{2} \mathrm{O}_{3}$ converts to $\mathrm{Fe}_{2} \mathrm{O}_{3}$ (i.e. hematite) and, similar to the oxidation of $\mathrm{Fe}_{2.73} \mathrm{Ti}_{0.27} \mathrm{O}_{4}$ to $\gamma-\mathrm{Fe}_{2} \mathrm{O}_{3}$, the conversion is effectively complete with the result being titanium-bearing $\mathrm{Fe}_{2} \mathrm{O}_{3}$ and minor ferrous pseudobrookite $\left(\mathrm{Fe}_{2} \mathrm{TiO}_{5}\right)$. Finally, at $\mathrm{T}>\sim 1523 \mathrm{~K}$ the $\mathrm{Fe}_{2} \mathrm{O}_{3}$ reduces to titanium-bearing magnetite (designated as $\mathrm{Fe}_{3} \mathrm{O}_{4}$ in Figs. 1 and 3 since the Ti concentration in the phase is unknown).

\subsection{Effect of Ironsand on SFCA-I Formation in Mix- tures Designed to form SFCA-I}

Figure 4 shows the plot of accumulated in situ XRD data for the $6.7 \mathrm{mass} \%$ ironsand/SFCA-I mixture (0.5 mass $\%$ $\mathrm{TiO}_{2}$ ). Reflections for $\mathrm{Fe}_{2} \mathrm{O}_{3}, \mathrm{Fe}_{2.73} \mathrm{Ti}_{0.27} \mathrm{O}_{4}, \mathrm{CaCO}_{3}$ (ICDD 5-0586) and $\mathrm{Al}(\mathrm{OH})_{3}$ (ICDD 33-0018) were observed at room temperature. Due to their low abundance $(<0.1$ mass\%) in this mixture, reflections for $\mathrm{FeTiO}_{3}$ and $\mathrm{SiO}_{2}$ were not observed. The first event was the decomposition

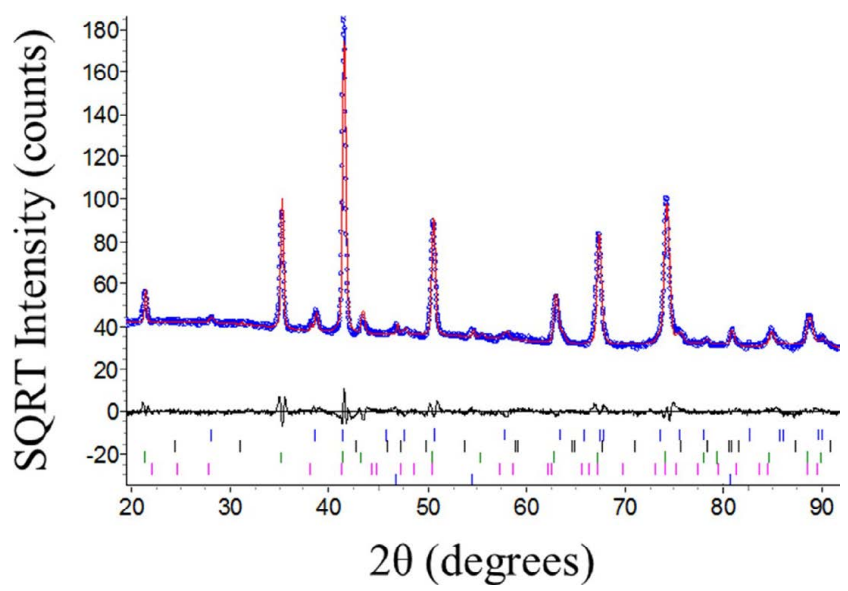

Fig. 2. Rietveld fit to the dataset collected for the ironsand sample at $298 \mathrm{~K}$. Experimental data are shown as open circles, the calculated pattern a continuous solid line and the difference pattern the solid line below. The vertical lines are the Bragg reflection markers for (upper to lower) $\mathrm{Fe}_{2} \mathrm{O}_{3}, \mathrm{SiO}_{2}$, $\mathrm{Fe}_{2.73} \mathrm{Ti}_{0.27} \mathrm{O}_{4}, \mathrm{FeTiO}_{3}$ and the Pt sample stage. (Online version in color.)

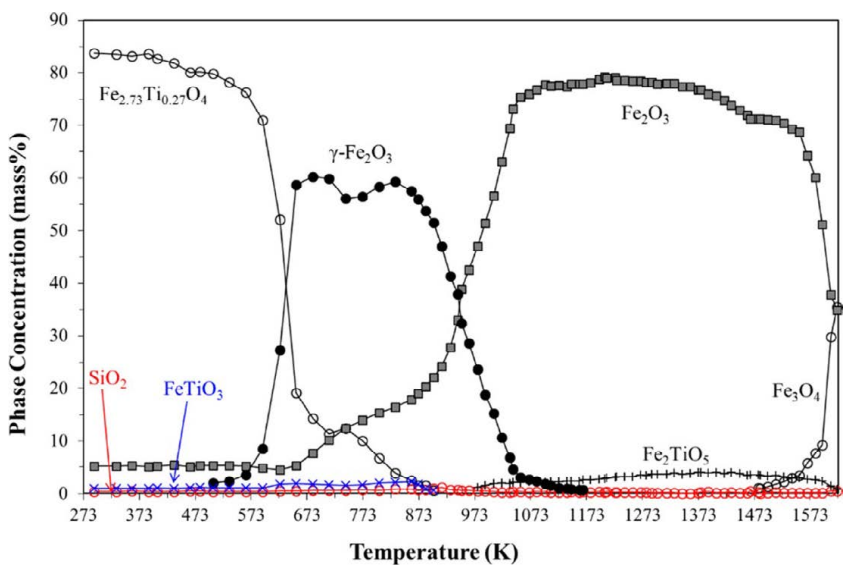

Fig. 3. Results of Rietveld-based QPA showing absolute phase concentrations as a function of temperature, for the ironsand sample. (Online version in color.) 


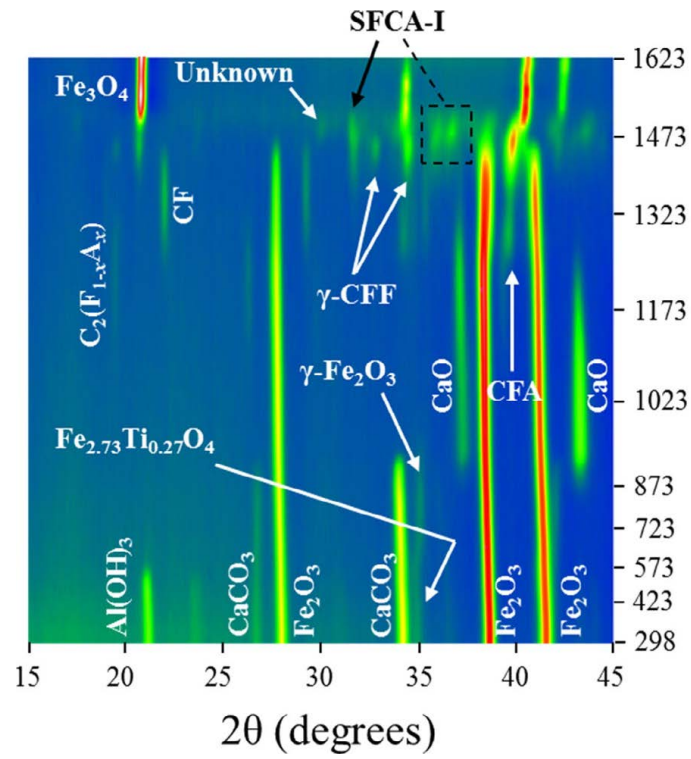

Fig. 4. In situ XRD data collected for the 6.7 mass $\%$ ironsand/ SFCA-I mixture. (Online version in color.)

of $\mathrm{Al}(\mathrm{OH})_{3}$ to amorphous Al-oxide which was complete by $591 \mathrm{~K}$. Then, $\mathrm{CaCO}_{3}$ decomposed to $\mathrm{CaO}$ (ICDD 37-1497), which was complete by $936 \mathrm{~K}$. Similar to what was observed for the ironsand sample discussed in Section 3.1, oxidation of $\mathrm{Fe}_{2.73} \mathrm{Ti}_{0.27} \mathrm{O}_{4}$ to $\gamma-\mathrm{Fe}_{2} \mathrm{O}_{3}$ was complete by $672 \mathrm{~K}$, with the conversion of $\gamma-\mathrm{Fe}_{2} \mathrm{O}_{3}$ at higher temperature resulting in the formation of additional (4.4 mass\%) and Ti-bearing $\mathrm{Fe}_{2} \mathrm{O}_{3}$.

The first Ca-rich ferrite to form was alumina-substituted dicalcium ferrite (designated hereafter as $\mathrm{C}_{2}\left(\mathrm{~F}_{1-x} \mathrm{~A}_{x}\right)$ (ICDD 01-089-8667) at $\sim 1053 \mathrm{~K}$, followed by $\mathrm{CF}$ (i.e. monocalcium ferrite, where $\mathrm{C}=\mathrm{CaO}$ and $\mathrm{F}=\mathrm{Fe}_{2} \mathrm{O}_{3}$, ICDD 3-065-1333) and CFA (a phase with average composition 71.7 mass $\% \mathrm{Fe}_{2} \mathrm{O}_{3}, 12.9$ mass $\% \mathrm{CaO}, 0.3$ mass $\% \mathrm{SiO}_{2}$ and 15.1 mass $\% \mathrm{Al}_{2} \mathrm{O}_{3},{ }^{9}$ ) ICDD 1-077-0676) at $\sim 233 \mathrm{~K}$. As the temperature increased further, SFCA-I (ICDD 52-1258) and $\gamma$-CFF (nominal composition $\mathrm{Ca}_{3.0} \mathrm{Fe}_{14.82} \mathrm{O}_{25}$, ICDD 1-078-1675) formed, at $\sim 1373 \mathrm{~K}$. Incongruent melting (i.e. solid $1 \rightarrow$ liquid + solid 2) of SFCA-I, which was complete by $1535 \mathrm{~K}$ (i.e. liquidus temperature), produced a phase assemblage of $\mathrm{Fe}_{3} \mathrm{O}_{4}$ (designated so because of the low overall $\mathrm{Ti}$ concentration in this mixture $(0.5 \mathrm{mass} \%)$, and the significant level of $\mathrm{Ca}$ and $\mathrm{Al}$ substitution into the $\mathrm{Fe}_{3} \mathrm{O}_{4}$ which has been observed in previous work ${ }^{10)}$ ) in a $\mathrm{Fe}_{2} \mathrm{O}_{3}-\left(\mathrm{Fe}_{3} \mathrm{O}_{4}\right)-\mathrm{CaO}-\mathrm{SiO}_{2}-\mathrm{Al}_{2} \mathrm{O}_{3}$-rich melt. In addition, similar to the results of Webster et al., ${ }^{12)}$ i) decomposition of $\gamma$-CFF resulted in the formation of an unknown phase (observed in the range 1465-1511 K) for which no suitable matches in the ICDD database could be found, and ii) SFCA was not observed. Similar events were observed in the in situ XRD data collected for the 1.3 and 13.8 mass $\%$ ironsand/SFCA-I mixtures. There was no evidence in the in situ XRD data for the formation of perovskite, which was the major Ti-bearing phase reported in the studies of Zhang et al., ${ }^{16)}$ Ren et $a l .{ }^{20)}$ and Dehghan-Manshadi et al. ${ }^{21)}$ Minor amounts of perovskite may be below the detection limit of this laboratory-based experimentation.

Figure 5 shows the results of the Rietveld refinementbased QPA for the 1.3 (Fig. 5(a)), 6.7 (Fig. 5(b)) and 13.8 mass\% (Fig. 5(c)) ironsand/SFCA-I mixtures. The increasing concentration of ironsand did not significantly affect
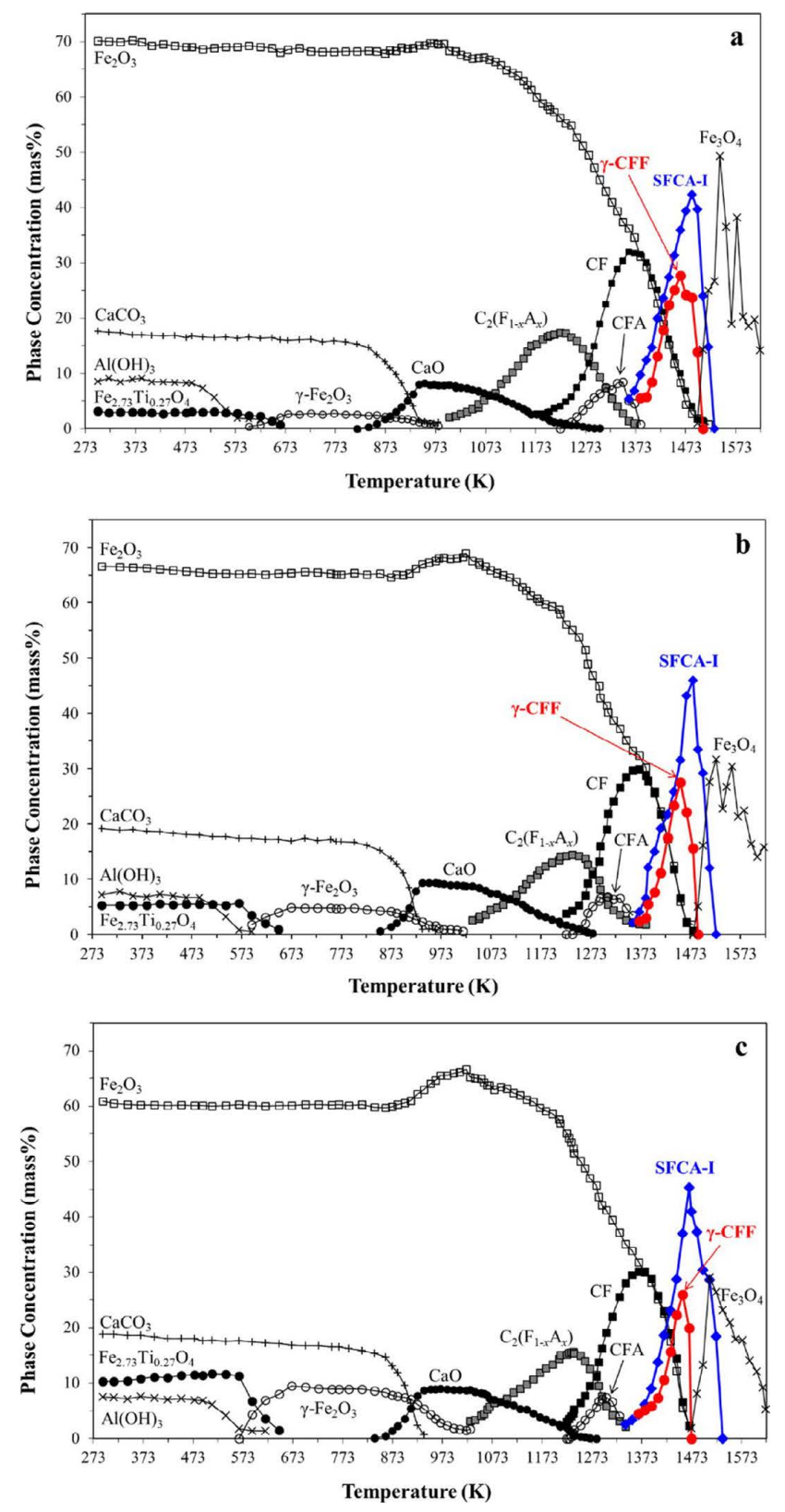

Fig. 5. Results of the Rietveld-based QPA for the (a) 1.3 mass $\%$, (b) $6.7 \mathrm{mass} \%$ and (c) $13.8 \mathrm{mass} \%$ ironsand/SFCA-I mixtures over the range $298-1623 \mathrm{~K}$. (Online version in color.)

the thermal stability range of SFCA-I, extending from $1370-1531 \mathrm{~K}$ for the 1.3 mass $\%$ mixture to $1366-1535$ $\mathrm{K}$ for the 13.8 mass $\%$ mixture. In addition, the maximum SFCA-I concentration attained was not markedly different between experiments; this was 42,46 and 45 mass $\%$ for the 1.3, 6.7 and 13.8 mass $\%$ mixtures, respectively. The main effect of ironsand addition was a small reduction in the thermal stability range of $\gamma$-CFF, from 1405 to $1496 \mathrm{~K}$ in the 1.3 mass $\%$ ironsand mixture, to 1405 to $1472 \mathrm{~K}$ in the 13.8 mass \% ironsand mixture. The scatter in $\mathrm{Fe}_{3} \mathrm{O}_{4}$ concentration observed for the 1.3 mass $\%$ ironsand mixture, in particular, is due to poor particle statistics in the region where significant melt generation has occurred (i.e. a relatively small number of $\mathrm{Fe}_{3} \mathrm{O}_{4}$ crystallites in a significant amount of melt phase). ${ }^{12,13)}$ The amount of $\mathrm{Fe}_{3} \mathrm{O}_{4}$ which formed, therefore, was similar in each experiment $(\sim 25 \mathrm{mass} \%)$.

In each of the SFCA-I/ironsand mixtures investigated here, the maximum concentrations of the precursor phases 
(i.e. $\mathrm{Fe}_{2} \mathrm{O}_{3}, \mathrm{C}_{2}\left(\mathrm{~F}_{1-x} \mathrm{~A}_{x}\right), \mathrm{CF}$ and CFA) were similar in each experiment, further suggesting a lack of effect of the ironsand on SFCA-I formation and stability. The di- and monocalcium ferrites are known to incorporate $\sim 5$ mass $\% \mathrm{TiO}_{2}$ substituting for $\mathrm{Fe}_{2} \mathrm{O}_{3}$, ${ }^{40}$ and it is likely that the Ti has been primarily incorporated into these early-formed phases. The main implication of the results presented here in Section 3.2 is that any degradation in sinter quality with increasing ironsand concentration, up to levels of 13.8 mass $\%$ addition of ironsand to the ultrafine component of a sinter blend, is not likely to be due to a reduction in the abundance of SFCA-I in the final sinter microstructure. Further work is required to establish at what level of ironsand addition a significant effect on SFCA-I formation becomes important.

\subsection{Effect of Ironsand on SFCA-I and SFCA Forma- tion in Mixtures Designed to form SFCA}

Figure 6 shows the plot of accumulated in situ XRD data for the $11.6 \mathrm{mass} \%$ ironsand/SFCA mixture (0.9 mass $\%$ $\mathrm{TiO}_{2}$ ). Similar phases and phase formation/decomposition events were observed here when compared to what was observed in Fig. 4, with the exception of (i) the presence of quartz (ICDD 33-1161), (ii) the detection of minor perovskite (designated as $\mathrm{CaTi}_{1-x} \mathrm{Fe}_{x} \mathrm{O}_{3-\delta}$, ICDD 01-0724765 ) in the experiment performed for the 11.6 mass $\%$ mixture, (iii) the formation/decomposition of SFCA (ICDD 46-0037), and (iv) the lack of formation of significant $\gamma$-CFF. With respect to quartz, the transformation of $\alpha-\mathrm{SiO}_{2}$ to $\beta-\mathrm{SiO}_{2}$ was completed by $860 \mathrm{~K}$ which is within experimental uncertainty of the $846 \mathrm{~K}$ value reported by Kihara ${ }^{41)}$ and gives confidence in the accuracy of the temperature measurements.

Figure 7 shows the results of the Rietveld refinementbased QPA for the 2.4 (Fig. 7(a)), 3.9 (Fig. 7(b)) and 11.6 mass\% (Fig. 7(c)) ironsand/SFCA mixtures. Most significantly, increasing ironsand concentration affected both the thermal stability range and the maximum concentration of the SFCA-I and SFCA phases. For SFCA-I, the thermal

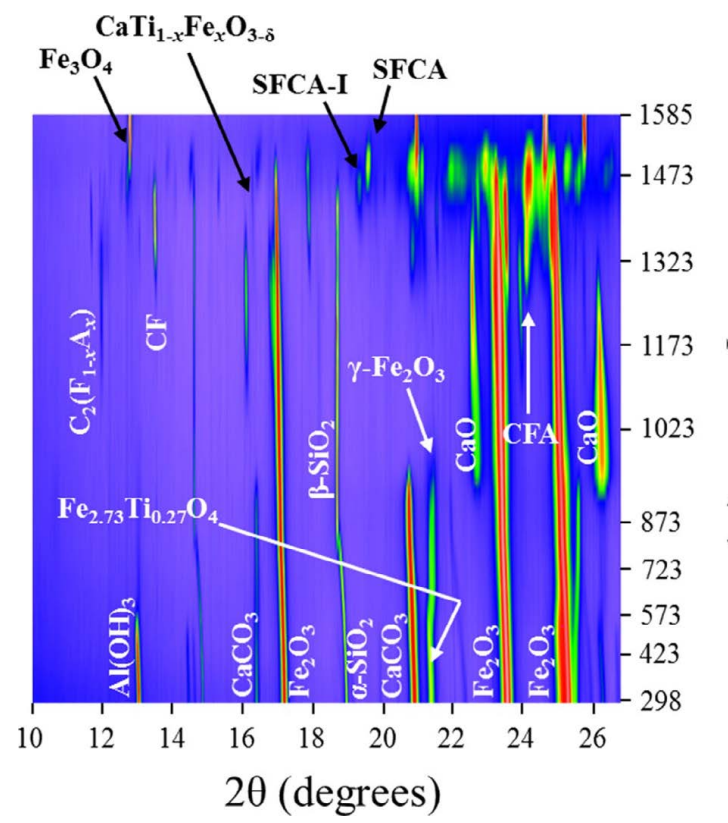

Fig. 6. In situ S-XRD data collected for the $11.6 \mathrm{mass} \%$ ironsand/ SFCA mixture. (Online version in color.) stability range was reduced from between $\sim 1307-1521 \mathrm{~K}$ for the 2.4 mass $\%$ mixture to between $\sim 1346-1513 \mathrm{~K}$ for the 11.6 mass $\%$ mixture, and the maximum concentration reduced from 30, to 24 and 16 mass $\%$ for the 2.4, 3.9 and 11.6 mass $\%$ ironsand mixtures, respectively. For SFCA, the thermal stability range was reduced from $\sim 1354-1521$ $\mathrm{K}$ for the 2.4 mass $\%$ mixture to $\sim 1442-1560 \mathrm{~K}$ for the 11.6 mass $\%$ mixture, whereas the maximum concentration increased from 16, to 23 and 33 mass\% for the 2.4, 3.9 and 11.6 mass $\%$ ironsand mixtures, respectively.

The trends in maximum SFCA-I and SFCA concentrations suggest that SFCA is likely to incorporate more $\mathrm{Ti}$ in its crystal structure than SFCA-I, and the EPMA compositional results summarised in Tables 2 and 3 confirm this hypothesis. SFCA-I contains up to 0.6 mass $\% \mathrm{TiO}_{2}$, and SFCA 1.2 mass \% in air and at equilibrium. The results also confirm the presence of $\mathrm{Ti}$ in $\mathrm{Fe}_{2} \mathrm{O}_{3}$, as well as indicating that the perovskite contains a significant amount of $\mathrm{Fe}$.
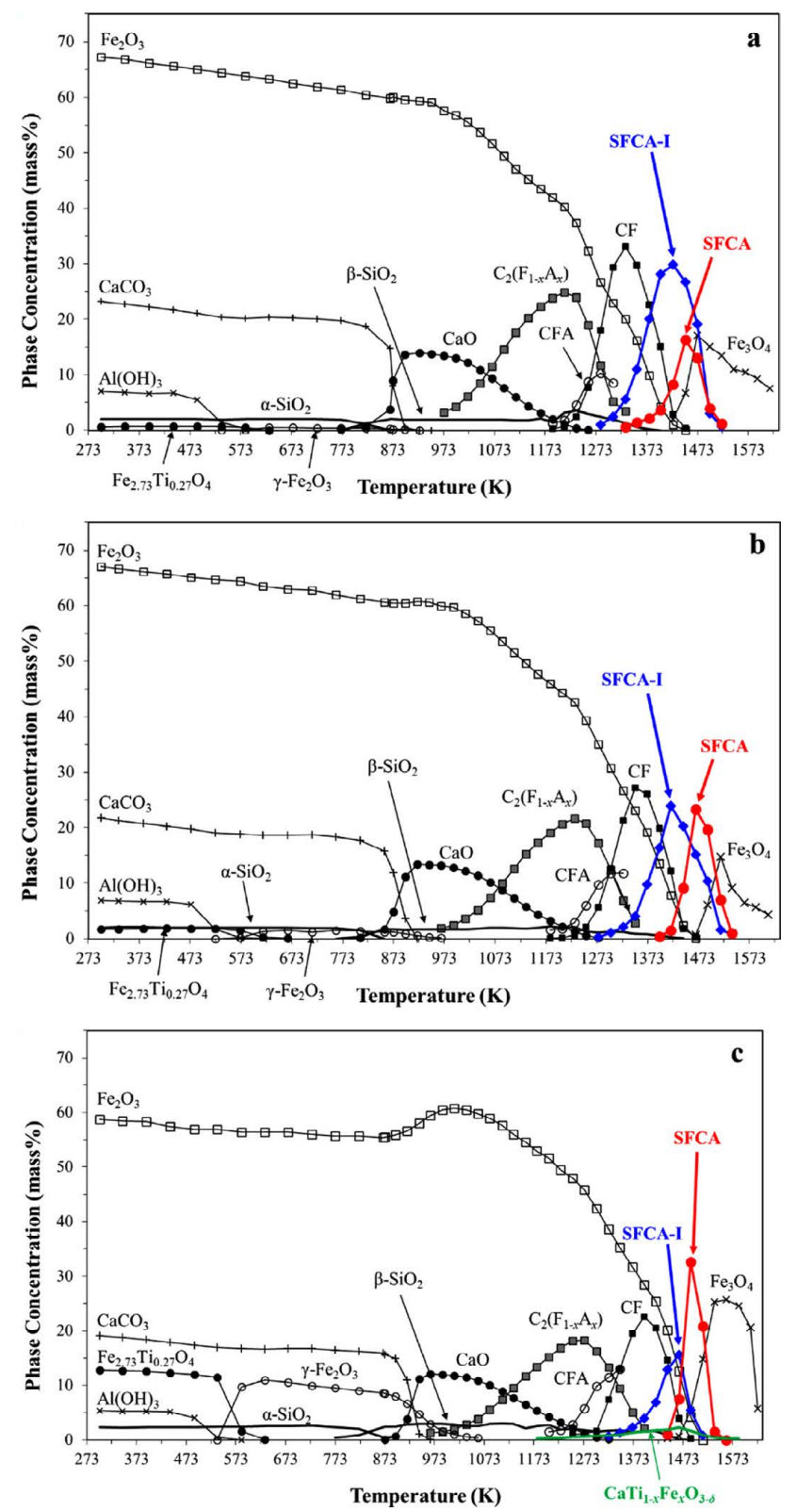

Fig. 7. Results of the Rietveld-based QPA for the (a) 2.4 mass $\%$, (b) $3.9 \mathrm{mass} \%$ and (c) $11.6 \mathrm{mass} \%$ ironsand/SFCA mixtures over the range $298-1623 \mathrm{~K}$. (Online version in color.) 
Table 2. Summary of the EPMA compositional results for the products of the phase equilibria experiments (all $\mathrm{Ti}$ added as $\mathrm{TiO}_{2}$ ) performed for SFCA-I-1TiO, SFCA-I-2TiO 2 and SFCA-I-3TiO ${ }_{2}$ at $1513 \mathrm{~K}$.

\begin{tabular}{|c|c|c|c|c|c|c|}
\hline \multirow[b]{2}{*}{ Phase } & \multicolumn{6}{|c|}{ Composition (oxide mass\%) } \\
\hline & $\mathrm{Fe}_{2} \mathrm{O}_{3}$ & $\mathrm{CaO}$ & $\mathrm{SiO}_{2}$ & $\mathrm{Al}_{2} \mathrm{O}_{3}$ & $\mathrm{TiO}_{2}$ & Total \\
\hline \multicolumn{7}{|l|}{$S F C A-1$} \\
\hline${\text { SFCA-I- } 1 \mathrm{TiO}_{2}}_{2}$ & $82.14(0.37)$ & $13.33(0.08)$ & $0.04(0.01)$ & $4.74(0.06)$ & $0.33(0.02)$ & $100.59(0.37)$ \\
\hline SFCA-I-2 $\mathrm{TiO}_{2}$ & $82.15(0.43)$ & $13.17(0.07)$ & $0.04(0.01)$ & $5.08(0.04)$ & $0.43(0.05)$ & $100.88(0.40)$ \\
\hline SFCA-I-3 $\mathrm{TiO}_{2}$ & $80.41(0.69)$ & $13.03(0.31)$ & $0.04(0.01)$ & $6.29(0.57)$ & $0.63(0.23)$ & $100.41(0.40)$ \\
\hline \multicolumn{7}{|l|}{$\mathrm{Fe}_{2} \mathrm{O}_{3}$} \\
\hline${\mathrm{SFCA}-\mathrm{I}-1 \mathrm{TiO}_{2}}_{2}$ & $97.88(0.64)$ & $0.36(0.06)$ & $0.00(0.01)$ & $1.00(0.06)$ & $0.97(0.12)$ & $100.21(0.63)$ \\
\hline SFCA-I- $2 \mathrm{TiO}_{2}$ & $98.08(0.44)$ & $0.38(0.08)$ & $0.00(0.01)$ & $1.13(0.02)$ & $1.15(0.03)$ & $100.74(0.43)$ \\
\hline SFCA-I-3TiO ${ }_{2}$ & $97.48(0.37)$ & $0.31(0.07)$ & $0.00(0.01)$ & $1.34(0.13)$ & $1.25(0.13)$ & $100.38(0.41)$ \\
\hline \multicolumn{7}{|l|}{ Perovskite } \\
\hline 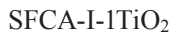 & $17.80(2.56)$ & $39.05(1.62)$ & $0.06(0.02)$ & $0.74(0.19)$ & $41.08(2.20)$ & $98.73(1.12)$ \\
\hline SFCA-I-2 $\mathrm{TiO}_{2}$ & $14.01(1.92)$ & $40.12(0.67)$ & $0.13(0.04)$ & $0.51(0.13)$ & $44.87(1.75)$ & $99.63(0.53)$ \\
\hline SFCA-I- $3 \mathrm{TiO}_{2}$ & $11.71(1.59)$ & $40.05(1.04)$ & $0.09(0.02)$ & $0.53(0.15)$ & $46.15(1.62)$ & $98.52(0.82)$ \\
\hline
\end{tabular}

Table 3. Summary of the EPMA compositional results for the products of the phase equilibria experiments (all Ti added as $\mathrm{TiO}_{2}$ ) performed for $\mathrm{SFCA}-1 \mathrm{TiO}_{2}, \mathrm{SFCA}-2 \mathrm{TiO}_{2}$ and $\mathrm{SFCA}-3 \mathrm{TiO}_{2}$ at $1533 \mathrm{~K}$. The numbers in parentheses are the standard deviation of the $\sim 10$ point analyses for each phase. Where numbers in parentheses are not present, the composition is from an individual point.

\begin{tabular}{|c|c|c|c|c|c|c|}
\hline \multirow[b]{2}{*}{ Phase } & \multicolumn{6}{|c|}{ Composition (oxide mass\%) } \\
\hline & $\mathrm{Fe}_{2} \mathrm{O}_{3}$ & $\mathrm{CaO}$ & $\mathrm{SiO}_{2}$ & $\mathrm{Al}_{2} \mathrm{O}_{3}$ & $\mathrm{TiO}_{2}$ & Total \\
\hline \multicolumn{7}{|l|}{$S F C A$} \\
\hline $\mathrm{SFCA}-1 \mathrm{TiO}_{2}$ & $75.92(0.69)$ & $14.45(0.17)$ & $3.36(0.17)$ & $5.44(0.11)$ & $1.17(0.03)$ & $100.34(0.51)$ \\
\hline $\mathrm{SFCA}-2 \mathrm{TiO}_{2}$ & $74.71(0.50)$ & $14.72(0.20)$ & $3.66(0.24)$ & $5.93(0.23)$ & $1.23(0.08)$ & $100.25(0.47)$ \\
\hline SFCA-3 $\mathrm{TiO}_{2}$ & 73.95 (1.67) & $14.99(0.43)$ & $3.94(0.51)$ & $6.82(0.83)$ & $1.17(0.10)$ & $100.86(0.52)$ \\
\hline \multicolumn{7}{|l|}{$\mathrm{Fe}_{2} \mathrm{O}_{3}$} \\
\hline $\mathrm{SFCA}^{-1 \mathrm{TiO}_{2}}$ & $97.47(0.67)$ & $0.39(0.04)$ & $0.02(0.02)$ & $1.02(0.02)$ & $1.62(0.02)$ & $100.52(0.41)$ \\
\hline SFCA-2 $\mathrm{TiO}_{2}$ & $96.34(0.74)$ & $0.53(0.14)$ & $0.02(0.02)$ & $1.10(0.04)$ & $1.79(0.03)$ & $99.77(0.82)$ \\
\hline $\mathrm{SFCA}-3 \mathrm{TiO}_{2}$ & $98.31(0.43)$ & $0.45(0.04)$ & $0.02(0.02)$ & $1.08(0.02)$ & $1.92(0.07)$ & $101.78(0.69)$ \\
\hline \multicolumn{7}{|l|}{ Perovskite } \\
\hline SFCA-1TiO 2 & 16.31 & 40.76 & 2.59 & 0.55 & 38.94 & 99.15 \\
\hline $\mathrm{SFCA}-2 \mathrm{TiO}_{2}$ & $17.63(4.48)$ & $39.26(2.17)$ & $2.67(0.36)$ & $0.79(0.47)$ & $38.76(3.95)$ & 99.12 (1.08) \\
\hline SFCA- $3 \mathrm{TiO}_{2}$ & $15.04(1.60)$ & $39.82(1.22)$ & $2.33(0.21)$ & $0.59(0.09)$ & $40.49(1.72)$ & $98.28(1.18)$ \\
\hline
\end{tabular}

Perovskite in the $\mathrm{CaO}$ - iron oxide $-\mathrm{TiO}_{2}$ system in air can accommodate as much as $83 \%$ of $\mathrm{Fe}$ in substitution for $\mathrm{Ti}^{40)}$ The Ti substitution mechanism(s) within SFCA and SFCA-I are unclear from the data in Tables 2 and 3, and further work is required to determine this.

The trends in maximum concentrations may also help to explain the observations of Bristow and Loo $^{18)}-$ i.e. that titanomagnetite content of greater than 3 mass $\%$ had a significant negative effect on sinter properties - since SFCA-I is generally considered to be the more desirable bonding phase for promoting sinter quality than SFCA. Furthermore, Fig. 8 shows a plot of the 'total SFCA' concentration (i.e. SFCA-I + SFCA) produced for each of the ironsand/SFCA mixtures. The area under the curve decreases as the ironsand content in the starting sinter mixture increases, and so the likelihood of retaining the key bonding matrix materials in the sinter microstructure during heating are also reduced. Figure 8 also shows that in order to maximise the amounts of bonding matrix material during heating, higher sintering temperatures would be required as the ironsand content is increased. This would likely have implications for fuel (i.e. coke breeze) consumption and overall productivity. As well, it is noted that Bristow and Loo ${ }^{18)}$ postulated that the addition of titanium decreased the fracture toughness of the retained glass, typically the weakest phase in iron ore sinter, thereby increasing the vulnerability of the sinter to crack propagation and lowering the RDI. It is important, therefore, to investigate the effect of ironsand addition on phase for- 


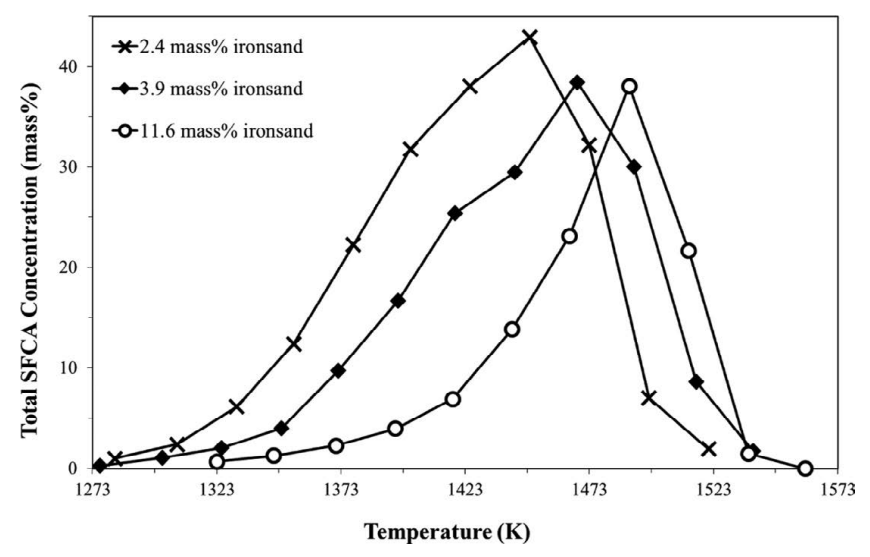

Fig. 8. Total SFCA (i.e. SFCA-I + SFCA) concentration as a function of temperature for the 2.4, 3.9 mass $\%$ and 11.6 mass $\%$ ironsand/SFCA mixtures.

mation during cooling using in situ diffraction, to determine the nature and abundance of phases (including SFCA) which crystallise from the melt during cooling, thereby affecting the retained glass.

\section{Conclusion}

The effects of ironsand addition on the thermal stability and concentration of SFCA-I and SFCA iron ore sinter bonding phases during heating were determined using in situ diffraction techniques with subsequent Rietveld refinementbased quantitative phase analysis. Results showed that, for starting sinter mixtures with bulk compositions designed to form SFCA-I, increasing the ironsand concentration up to 13.8 mass $\%$ did not significantly affect the thermal stability range of SFCA-I or the maximum concentration of SFCA-I. However, for starting sinter mixtures with bulk compositions designed to form SFCA, increasing the ironsand concentration from 2.4 to 3.9 and 11.6 mass $\%$ resulted in a reduction in the thermal stability range of both SFCA and SFCA-I, and caused a reduction in the amount of SFCA-I with an associated increase in the amount of SFCA. Phase equilibria experiments showed that SFCA accommodates more Ti in its crystal structure than SFCA-I. Future work will investigate the effect of ironsand addition/Ti on phase formation during cooling, since retained glass and SFCA phases which have crystallized from the melt are a significant component of the microstructure of typical industrial sinters.

\section{Acknowledgements}

The Australian Nuclear Science and Technology Organisation (ANSTO) is acknowledged for financial support of this research. This research was partially undertaken on the powder diffraction beamline (10BM1) at the Australian Synchrotron, Victoria, Australia, under beamtime award AS132/PD6321. The authors wish to thank: Drs Bree Morgan and Barry Halstead (both CSIRO Mineral Resources) for assistance with synchrotron data collection; Dr David Pinson (BlueScope Steel) and Dr Zhe Wang (Uni- versity of Wollongong) for providing the ironsand sample; Dr Nick Wilson (CSIRO Mineral Resources) for assistance with EPMA; and Professor George Franks (University of Melbourne) for support of this research. Felipe Tufaile thanks the Science Without Borders program for providing the opportunity to study in Australia.

\section{REFERENCES}

1) I. Tonžetić and A. Dippenaar: Miner. Eng., 24 (2011), 1258.

2) W. G. Mumme, J. M. F. Clout and R. W. Gable: N. Jahrb. Mineral. Abh., 173 (1998), 93.

3) J. Hancart, V. Leroy and A. Bragard: CNRM Metall. Rep., DS 24/67, (1967), 3.

4) S. N. Ashan, T. Mukkerjee and J. A. Whiteman: Ironmaking Steelmaking, 10 (1983), 54

5) T. R. C. Patrick and M. I. Pownceby: Metall. Mater. Trans. B, 32 (2001), 1.

6) M. Sasaki and Y. Hida: Tetsu-to-Hagané, 68 (1982), 563.

7) J. McAndrew and J. M. F. Clout: Proc. 4th China-Australia Symp. on Technology of Feed Preparation for Ironmaking, Dampier, Australia, (1993), 1.

8) N. V. Y. Scarlett, M. I. Pownceby, I. C. Madsen and A. Christensen: Metall. Mater. Trans. B, 35 (2004), 929.

9) N. V. Y. Scarlett, I. C. Madsen, M. I. Pownceby and A. N. Christensen: J. Appl. Crystallogr., 37 (2004), 362.

10) N. A. S. Webster, M. I. Pownceby, I. C. Madsen and J. A. Kimpton: Metall. Mater. Trans. B, 43 (2012), 1344.

11) N. A. S. Webster, M. I. Pownceby, I. C. Madsen and J. A. Kimpton: ISIJ Int., 53 (2013), 774.

12) N. A. S. Webster, M. I. Pownceby and I. C. Madsen: ISIJ Int., 53 (2013), 1334.

13) N. A. S. Webster, M. I. Pownceby, I. C. Madsen, A. J. Studer, J. R. Manuel and J. A. Kimpton: Metall. Mater. Trans. B, 45 (2014), 2097.

14) N. A. S. Webster, M. I. Pownceby, I. C. Madsen, A. J. Studer and J. A. Kimpton: Powder Diffr., 29 (2014), S54.

15) J. D. G. Hamilton, B. F. Hoskins, W. G. Mumme, W. E. Borbidge and M. A. Montague: N. Jahrb. Mineral. Abh., 161 (1989), 1.

16) Z. Wang, D. Pinson, S. Chew, H. Rogers, B. J. Monaghan, M. I. Pownceby, N. A. S. Webster and G. Zhang: Metall. Mater. Trans. B, 37 (2016), 330.

17) Y. Li, Y. Q. Li and R. J. Fruehan: ISIJ Int., 41 (2001), 1417.

18) N. J. Bristow and C. E. Loo: ISIJ Int., 32 (1992), 819.

19) T. Paananen and K. Kinnunen: Steel Res. Int., 80 (2009), 408.

20) S. Ren, J. L. Zhang, L. S. Wu, B. X. Su, X. D. Xing and G. Y. Zhu: Ironmaking Steelmaking, 41 (2013), 132

21) A. Dehghan-Manshadi, J. Manuel, S. Hapugoda and N. Ware: ISIJ Int., 54 (2014), 2189.

22) L-H. Hsieh and J. A. Whiteman: ISIJ Int., 29 (1989), 24.

23) K. Wallwork, B. Kennedy and D. Wang: AIP Conf. Proc., 879 (2007), 879

24) Bruker AXS Inc.: TOPAS Version 5, Bruker AXS Inc., Madison, Wisconsin, (2014).

25) R. Blake, R. Hessevick, T. Zoltai and L. Finger: Am. Mineral., 51 (1966), 123.

26) E. N. Maslen, V. A. Strel'tsov, N. R. Strel'tsova and N. Ishizawa: Acta Crystallogr. B, 51 (1995), 929.

27) H. Saalfeld and M. Wedde: Z. Krystallogr. Krist., 139 (1974), 129.

$28)$ G. A. Lager, J. D. Jorgensen and F. J. Rotella: J. Appl. Phys., 53 (1982), 6751.

29) H. Schulz and V. Tscherry: Acta Crystallogr. B, 28 (1972), 2168.

30) I. Oftedal: Z. Phys. Chem., 128 (1927), 135.

31) P. Berastegui, S.-G. Eriksson and S. Hull: Mater. Res. Bull., 34 (1999), 303

32) D. F. Decker and J. S. Kasper: Acta Crystallogr., 10 (1957), 332.

33) A. V. Arakcheeva, O. G. Karpinskii and V. Ya. Lyadova: Kristallografiya, 36 (1991), 603.

34) A. V. Arakcheeva and O. G. Karpinskii: Sov. Phys. Crystallogr., 32 (1987), 31

35) W. C. Hamilton: Phys. Rev, 110 (1958), 1050

36) B. A. Wechsler, D. H. Lindsley and C. T. Prewitt: Am. Mineral., 69 (1984), 754.

37) C. Pecharroman, T. Gonzalez-Carreno and J. E. Iglesias: Phys. Chem. Miner., 22 (1995), 21

38) A. I. Becerro, S. A. T. Redfern, M. A. Carpenter, K. S. Knight and F. Seifert: J. Solid State Chem., 167 (2002), 459.

39) L. Pauling: Z. Kristallogr. Krist., 73 (1930), 97.

40) S. Kimura and A. Muan: Am. Mineral., 56 (1971), 1332.

41) K. Kihara: Eur. J. Miner., 2 (1990), 63. 